\title{
Legal Implications on the Use of the Name of Semongkat Village as a Trademark
}

\author{
Isnaini Kurniawan Lalu Wira Suhartana \\ Notary Master Study Program, Faculty of Law, University of Mataram, Indonesia
}

\begin{abstract}
The purpose of this study is to analyze the legal validity of the use of the name Semongkat hamlet as a trademark, to analyze the legal protection of the Semongkat hamlet community for the use of their regional name as a trademark, and to find out and analyze the legal efforts made by the Semongkat hamlet community. The normative-empirical research method uses the Legislative approach, the Historical Approach and the Sociological Approach. From the results of the research, the first results are obtained, based on the results of the analysis of Article 20 letter f of Law Number 20 of 2016 concerning Brands and Geographical Indications, that the name Semongkat is a generic term category so it must be cancelled as a registered brand. Second, Registration of the name of Semongkat hamlet as a collective brand or registration of Semongkat area as a geographical indication is a legal effort in protecting the rights of the people of Semongkat hamlet. Third, for the use of the name Semongkat as a registered trademark, the people of Semongkat hamlet may file legal action through mediation, arbitration or lawsuits through the courts.
\end{abstract}

Keywords: Validity, Trademark, Semongkat, generic term

DOI: $10.7176 / \mathrm{JLPG} / 112-01$

Publication date:August $31^{\text {st }} 2021$

\section{INTRODUCTION}

Semokat Hamlet is one of the areas located in the village of Klungkung, Batulanteh District, Sumbawa Regency, West Nusa Tenggara Province. This hamlet is very strategic because it is the capital of the Batulanteh subdistrict, besides that it has promising natural potential with fertile nature. The potential that exists in Semongkat hamlet is nature tourism, clean water, honey, ginger, and other natural products, with this potential being the main attraction for investors to invest.

The issue in this study is the use of the name of hamlet Semongkat which is the name of an area used as a trademark in some businesses, such as bottled water (AMDK) business, honey products, ginger, coffee, cocoa, sago, and tapioca, this type of brand is contrary to the validity of the registration of a brand.

The purpose of this study is to Explain and analyze about the legal consequences and validity of the use of the name Semongkat as a registered trademark, Explain and analyze clearly about the legal protection against the use of the name Semongkat as a registered trademark and explain what legal efforts against the use of the name Semongkat as a registered brand.

The benefits of research, this research is expected to contribute ideas for the development of Legal Science in general and in particular regarding the use of registered trademarks that use the name Semongkat as a registered trademark in Sumbawa Regency and Practically the results of this study are expected to provide the right thoughts and solutions for the community, entrepreneurs, as well as policy making in the use of the name of a region or a generic term to become a registered trademark.

Normative-empirical research method. ${ }^{1}$ The research approach is the Legislative Approach, the Historical Approach, ${ }^{2}$ and Legal Sociology Approach. ${ }^{3}$ The types and sources of data are primary and secondary data. ${ }^{4}$ The research location is in Semongkat Hamlet, Klungkung Village, Batulanteh District. Data collection techniques or legal materials include techniques for collecting primary materials and collecting secondary data. Data processing is processed in a sequential and systematic manner. The data analysis in this study is qualitative, comprehensive, and complete. ${ }^{5}$

The results of the research are, First, the use of the name Semongkat as a trademark is included in the generic term category so that it is contrary to Article 20 Letter f of Law Number 20 of 2016 concerning Brands and Geographical Indications, Regional names are signs that are public property, so they cannot be registered as trademarks. Because one of the requirements for a sign to be made a mark is not a sign that is public property. A brand is one of the regimes whose ownership is individual. Second, Article 20 and Article 22 of Law Number 20 of 2016 concerning Brands and Geographical Indications are the basis for legal protection for the people of Semongkat hamlet for the use of their regional names as trademarks, therefore as a form of justice for the use of

\footnotetext{
${ }^{1}$ Muhaimin, Metode Penelitian Hukum, Mataram University Press, Mataram, 2020, Hlm. 118.

2 Salim HS \& Erlies Septiana Nurbani, Op. Cit. Hal.23

${ }^{3}$ Soerjono Soekanto \& Sri Mamudji, Penelitian Hukum Normatif Suatu Tinjauan Singkat, PT. Jakarta, Raja Grafindo Persada, 2003 , hlm. 13.

${ }^{4}$ Muhaimin, Metode Penelitian Hukum, Op. Cit. Hal. 89

${ }^{5}$ Ibid
} 
the name, cancellation of the registration of the name Semongkat must be filed as a trademark. The trademark in the name of Semongkat needs to be registered as a collective mark with a different name or with additional words so that it is not included in the Generic Term element. Collective marks can be used together by the people of Semongkat Hamlet. Third, Law 20 of 2016 concerning Brands and Geographical Indications has guaranteed legal certainty for interested parties who feel disadvantaged by the registration of a mark, the community of Semongkat hamlet as a party that is harmed by the use of the name Semongkat as a business has certainly been arranged about legal efforts made by the community of Semongkat hamlet that must be taken, namely in Chapter XII Part two concerning the cancellation of marks, it can also be through mediation, through arbitration and through court lawsuits to cancel the registration of the name Semongkat as a trademark.

Suggestions from the results of research and analysis are, First, in the law on Brands and Geographical Indications, it is regulated on the use of generic terms or generic terms, but in the explanation of article by article it is not explained in detail what the meaning of the use of generic terms is. Second, the use of regional names as trademarks results in many people being harmed because of the absence of ideas and abilities in making brands, so that it has an impact on the use of names that are already well known, both regional names and other generic terms, so it needs to be emphasized in the Brands and Geographical Indications (MIG) Law regarding the use of names. area as a brand, so that there is legal protection for the community whose area is used as a trademark. Third, as a result of the use of the name Semongkat, it is hoped that the government, especially the village government of Kelungkung, Batulanteh District, will participate in efforts to take legal action against the protection of the people of Semongkat hamlet, so that the economy in Klungkung village, especially in Semongkat hamlet can develop.

\section{DISCUSSION}

\section{Legal Validity of Company Brand Using Semongkat Name as Registered Trademark}

The positive legal system in Indonesia has already regulated in detail about trademarks, but has changed several times, starting with Law Number 21 of 1961 concerning Corporate Marks and Commercial Marks which was later changed to Law Number 19 of 1992 concerning Marks, Law No. Law Number 14 of 1997 concerning Marks and lastly changed to Law Number 20 of 2016 concerning Brands and Geographical Indications.

Changes to the Trademark Law in Indonesia from time to time are adjusted to the international convention on Intellectual Property Rights relating to Marks, namely the Trademark Law Treaty of 1995. According to Achmad Zen Umar, the Trademark Law Treaty in its development was embellished with the existence of TRIP (Trade-Related Aspects of Intellectual Property Rights), TRIP are international legal instruments), but TRIP are not the starting point for the growth of the concept of intellectual property rights. Various International Conventions have long been born, and have been amended several times. The significant and the main basis of the Industrial Property concept is the Paris Convention for the Protection of Industrial Property (Paris Convention), while in the field of copyright it is the Berne Convention for the Protection of Literaty and Artistic Works (Berne Convention). From the two conventions, intellectual property rights are traditionally divided into: industrial property, including patents, trademarks and industrial designs; and copyright and related rights. Prof. Michael Blakeney, outlines the scope of intellectual property rights as follows : ${ }^{1}$
a. Literaty, artisticand scientific works;
b. Performances of performing artists, phonograms and broadcasts,
c. Inventions in all fileds of human endeavour;
d. Scientific discoveries;
e. Industrial designs;
f. Trademarks, service marks and commercial names and g. designations;
h. Protection against unfair competition.

Indonesia's newest Brand Law, namely Law No. 20 of 2016 on Brands and Geographical Indications as a modifier of the old Brand Law Law No. 15 of 2001 on Brands, The Law of the Republic of Indonesia Number 20 of 2016, Regarding Brands and Geographical Indications has adopted the provisions of TRIPs, and this Law is the guideline in the current regulation of brands in Indonesia. The trademark registration process is also regulated more explicitly in Regulation of the Minister of Law and Human Rights number 67 of 2016 concerning the registration of brands, also regulates the registration of international brands, namely Government Regulation No. 22 of 2018 concerning International Mark Registration, in the Law on Brands and Geographical Indications the following describes the legal basis for types of brands to the removal and cancellation of registered brands.

The name Semongkat is registered for the types of trademarks in 2 classes as follows:

1. The name Semongkat is registered as a trademark by an entrepreneur named JOKO SUTOYO having his address at J1. Dr. Wahidin No. 20 RT 001 RW 01Brang Bara Village,

\footnotetext{
${ }^{1}$ Achmad Zen Umar Purba, Hak Kekayaan Intelektual Pasca TRIPs, Alumni, Bandung, 2005, hlm. 22.
} 
Sumbawa District, Sumbawa Regency, West Nusa Tenggara Province, with a class code of 32, type of goods and services Bottled Water (AMDK), registration number IDM000387417, protection start date 09-05-2011 extended 29-12-2020, protection period 09-05-2021, translation SEMONGKAT, in practice this trademark is marketed by PT. Samawa Tirta Alam which is located at Pelat village, Unter Iwis District, Sumbawa Regency.

2. The name Semongkat is registered as a trademark by the entrepreneur on behalf of NURHAYATI The village address is Penyaring RT 002/RW 006 Penyaring Village, North Moyo District, class code 30, for types of goods Rice, Sugar, Cocoa, Coffee, Honey, Sago, Tapioca, Tea, registration number IDM000726691, protection start date 2018-08-29, extended 2020-05-15, protection end date 2028-08-29, translation SEMONGKAT.

From the description above, the Semongkat brand is included as a word mark because it consists of an arrangement of words without any special symbols and special logos. By law, the Semongkat brand is included in the type of trademark.

To strengthen the argument that the name Semongkat is a public name, there are several basis, including: :

a. In Law number 20 of 2016 on brands and geographical indications

In the explanation of Article 20 letter $\mathrm{f}$ What is meant by "generic term" among others Brand "restaurant" for restaurant, Brand "coffee shop" for café, in this Article is not clear set on how the criteria of the generic term, so it has not been able to answer the word has become public property.

\section{b. In Jurisprudence}

In Indonesia, there is a jurisprudence that can be used as a reference in determining the criteria of the word publicly owned contained in Law No. 15 of 2001 on Brands, namely the decision no. 958K / Pdt.Sus / 2010 dated February 9, 2012 in a case at the cassation level between Sis Continents hotels, Inc. As the registered owner of "HOLIDAY INN" and "HOLIDAY INN RESORT" who filed for cancellation of the "HOLIDAY RESORT LOMBOK" brand owned by PT Lombok Seaside Cottage. According to Decision No. $958 \mathrm{~K} / \mathrm{Pdt}$.Sus $/ 2010$, the word has become public property the first is a word that is widely known by the public even though the word comes from a foreign language, the word is already commonly mentioned in the community and is already known as a general word, so the word is not monopolized by someone and cannot be used as a brand. The second is that the word public property is associated with another word so that it can be used as a mark and thus the word can be re-registered by another applicant. This is because if the general word is added to another word, it will cause a difference in understanding, thereby eliminating the general nature and other people can also use the word as a brand.

c. According to The Great Dictionary of The Indonesian Language

Linguistically, the definition of a generic term according to the Indonesian dictionary is about all or all of it; as a whole, does not concern the specific (certain) only, it can also contain meaning for many people; (for people) anyone, from the explanation of the Indonesian dictionary "Semongkat" it is a generic term based on the elements of the name.

\section{d. International Agreement}

Article 6 quinquies B paragraph 2 of the Paris Convention for the protection of Industrial Property states that the word public property is a word that has become a habit in the language of society or a habit in trade practices to describe things that are desired and goals to be achieved. The regulation of the word public property in the Paris Convention for the protection of Industrial Property explains the criteria for the word public property as a word that becomes a habit in society, but it should be more specific because words that have become a habit in the community are not only in the local language but can also be used in the community comes from a foreign language so the arrangement should be clearer. ${ }^{1}$

e. Legal expert opinion

In the Trademark Law book, Rahmi Jened P.N said that the general term (generic term) is as described below.

Brands that use generic terms are signs that describe the genus of their products. Generic terms are applied to the product and not just the terminology that is used to describe (descriptive) the product. This word refers to the consumer's understanding of the word. Any claim on the generic term to obtain the exclusive right to the mark must be rejected because its effect will give a monopoly right not only to the mark used as a mark. But also on the product. This makes the brand uncompetitive to be able to effectively name the product it seeks to sell. ${ }^{2}$

Judging from the historical naming of Semongkat hamlet through a long journey and through struggle and hard work by the community leaders who gave the name Semongkat, formerly the name Semongkat comes from the word tukokat which means to embrace, since long ago the name Semongkat has been known by all corners of

\footnotetext{
${ }^{1}$ Rini Silviya, Kriteria Unsur Milik Umum Dalam Pendaftaran Merek Berdasarkan Pasal 5 Huruf C Undang-Undang Nomor 15 Tahun 2001 Tentang Merek, Jurnal Universitas Atmajaya, 2016, hlm. 6.

${ }^{2}$ Rahmi Jened P.N. Op.Cit, h. 81-82.
} 
Sumbawa, because of its beauty and natural beauty, so that during the Sumbawa sultanate it was used as a bathing and resting place for the king of Sumbawa. ${ }^{1}$

Legal Protection for the Semongkat Hamlet Community for the Use of Semongkat Hamlet's Name as a Registered Trademark

Legal protection for the Semongkat hamlet community based on Law Number 20 of 2016 concerning Trademarks and Geographical Indications

Semongkat as a village administration area, the name Semongkat has been known for a long time by the community so that it is commonly spoken, when a brand using a generic term is a sign indicating or describing the genus or origin of the product. Any claim for registration of a trademark on generic terms to obtain exclusive rights to a mark must be rejected because the effect will give a monopoly right not only to the name used as a mark, but also to the products produced. ${ }^{2}$ The holder or owner of a registered trademark under the name "SEMONGKAT" first registers his trademark personally to register bottled water products, honey, coffee, rice, under the name "SEMONGKAT". It is known that Semongkat is the name of a hamlet in Sumbawa Regency.

The name Semongkat is a name where all the people of Semongkat Hamlet know that the hamlet is a hamlet that producing clean water, producing honey, which is known as a tourist center and water source. A name that has absolutely no distinguishing ability cannot be protected, although it has been used in an attempt to establish secondary meaning. It is known that it is unfair if something that is in the public domain becomes a brand and is monopolized by one party only, the name or mark included in this public domain includes: generic term, deceptively and geographically deceptively misdescriptive. ${ }^{3}$

Legal Protection of the Semongkat Hamlet Community based on international legal instruments

TRIPS AGREEMENT (Trade-Related Aspects Of Intellectual Property Rights)

The TRIPS AGREEMENT (Trade-Related Aspects Of Intellectual Property Rights) rule in part II of Article 17 (Exception Article) states that members may grant limited exemptions to rights conferred by trademarks, such as fair use of descriptive terms, provided that such exclusions take into account the legitimate interests of trademark owners and third parties).

"Members may provide limited exceptions to the rights conferred by a trademark, such as fair use of descriptive terms, provided that such exceptions take account of the legitimate interests of the owner of the trademark and of thir parties." 4

Semongkat has a descriptive meaning because it indicates a sign of origin, so in any product using the name Semongkat will describe that the origin of the item is from Semongkat Hamlet.

\section{World Intellectual Property Organization (WIPO)}

If a mark does not differ, the mark cannot function as a trademark and its registration must be rejected. Since this is the basis of denial of registration, the WIPO article states that trademarks are distinctive marks used to distinguish between the same goods and or similar services offered by different manufacturers or service providers.

The Legal Efforts of the Semongkat Hamlet Community Against the Use of the Semongkat Name as a Registered Trademark

Mediation as an initial effort in solving the problem of using the name of Semongkat hamlet as a trademark

Mediation is one of the forms of dispute resolution that can be chosen in resolving disputes in the field of IPR. Mediation is a form of basic application of the judicial trilogy that is not applied in the litigation process in court. The emergence of this non -litigation institution is due to the disappointment with the litigation process in the courts that never found the final solution of the settlement. The litigation line is essentially only intended to satisfy the emotional desires of one of the parties by seeing the other party lose to the judge's decision ${ }^{5}$, continued with other available legal efforts, so that in reality this dispute never ends and instead becomes a boomerang for the parties themselves.

Dispute Resolution in Court as an Effort of Semongkat Brand Cancellation Law

Brand dispute resolution is a process that takes place in resolving disputes, disputes or conflicts of trademark rights either through court (litigation) by filing a civil lawsuit in the form of damages to the court if the brand is used by another party without rights or through Dispute Resolution Alternatives ( APS) or non-

\footnotetext{
${ }^{1}$ Interview with Abdul Kahfi, Selaku Tokoh Masyarakat dan tokoh Agama dusun Semongkat, on 05 Maret 2021 at 12.00 Wita

${ }^{2}$ Rahmi Jened, Hak Kekayaan Intelektual Penyalahgunaan Hak Ekslusif, Airlangga University Press, Surabaya: 2007, hlm. 81

${ }^{3}$ Ibid, hlm. 159.

${ }^{4}$ World Trade Organization, “Agreement on Trade-related Aspects of Intellectual

Property Rights Part II - Standards concerning the availability, scope and use of IntelectualPropertyRights,"http://www.wto.org/english/tratop_e/trips_e/t_agm3_e.htm\#2, diunduh 4 April 2021

${ }^{5}$ D.Y. Witanto, 2012, Hukum Acara Mediasi, Alfabeta, Bandung, hlm. 9.
} 
litigation. The need for legal protection for brands is growing rapidly after many people commit acts of fraud such as piracy and imitation. Especially after the world of trade is more advanced and more advanced as well as better means of transportation, also with the promotion, the area of marketing of goods also becomes wider. ${ }^{1}$

\section{Alternatif Dispute Resolution}

Arbitration has become one of the patterns that has been widely accepted by industry and business in the settlement of disputes. ${ }^{2}$ Internationally, the World Intellectual Property Organization has an arbitration agency called WIPO Mediation \& Arbitration Center located in Geneva, Switzerland ${ }^{3}$, while the arbitration agency owned by Indonesia is the National Arbitration Agency (BANI) which is located in the region of Jakarta and has offices in other cities in Indonesia. ${ }^{4}$

\section{Conclusion}

The validity of the use of the name Semongkat as a trademark is invalid because it belongs to the category of generic terms so contrary to Article 20 letter f of Law No. 20 of 2016 concerning Brands and Geographical Indications, the name of the area is a sign that belongs to the public so it cannot be registered as a brand. Because one of the conditions of a sign to be used as a brand is not a sign that belongs to the public. based on the study of the name Semongkat entered as a category of generic and descriptive or general names that should not be interpreted as trademarks, no one can monopolize names that already belong to the public but the name belongs to the common.

The brand in the name of Semongkat does not have a distinguishing element because there are no additional words at the beginning or end of the word Semongkat, Article 20 and Article 22 of Law number 20 of 2016 concerning trademarks and geographical indications are the basis for legal protection for the people of Semongkat Hamlet for the use of their regional names as trademark, Therefore, as a form of justice for the use of the name, the cancellation of the registration of the Semongkat name as a trademark must be filed. The trademark in the name of Semongkat needs to be registered as a collective mark with a different name or with additional words so that it is not included in the Generic Term element.

Law 20 of 2016 on Brands And Geographical Indications already guarantees legal certainty to interested parties who feel disadvantaged by the registration of a brand, Semongkat Hamlet community as a party who feels aggrieved due to the use of their regional name, of course it has been regulated regarding legal remedies carried out by the Semongkat hamlet community, which is regulated in Chapter XII Part two concerning the cancellation of trademarks, it can also be through mediation, through arbitration and a court lawsuit to cancel the registration of a short name as a trademark.

\section{REFFERENCES}

\section{ARTICLES AND JOURNALS}

Ali, Z. (2011). Metode penelitian hukum. Sinar Grafika.

HS, H. S. (2016). Teknik Pembuatan Akta Satu: Konsep Teoritis. Kewenangan Notaris.

Leny, A. (2018). Panduan Notaris/PPAT dalam Menghadapi Gugatan Perdata. Yogyakarta : II Press Yogyakarta. Mertokusumo, S. (2009). Hukum Acara Perdata Indonesia (Edisi ke Delapan). Liberty, Yogyakarta.

Soegondo, R. (1982). Hukum Notariat di Indonesia Suatu Penjelasan. Rajawali Pers, Jakarta.

\section{REGULATIONS}

Kitab Undang-Undang Hukum Perdata;

Peraturan Menteri Agraria Dan Tata Ruang/Kepala Badan Pertanahan Nasional Nomor 2 Tahun 2018

Peraturan Pemerintah Nomor 24 Tahun 1997 tentang Pendaftaran Tanah;

Peraturan Pemerintah Nomor 37 Tahun 1998 tentang Peraturan Jabatan Pejabat Pembuat Akta Tanah;

Putusan Pengadilan Negeri Mataram Nomor 204/Pdt.G/2017/PN.Mtr.

Undang-Undang Dasar Negara Republik Indonesia Tahun 1945;

Undang-Undang Nomor 5 Tahun 1945 Tentang Peraturan Dasar Pokok-Pokok Agraria;

\section{INTERVIEW}

Wayan Parta, PPAT berkedudukan di Lombok Barat, pada tanggal 24 Mei 2021.

\footnotetext{
${ }^{1}$ Muhammad Djumhana dan R.Djubaedilah, Hak Milik Intelektual (Sejarah, Teori,dan Praktiknya di Indonesia), Bandung: PT Citra Aditya Bakti, 2011, hlm. 207

${ }^{2}$ Yuniar Kurniawaty, Efektivitas Alternatif Penyelesaian Sengketa Dalam

Sengketa Kekayaan Intelektual (Alternative Dispute Resolution On Intellectual Property

Dispute), Vol. 14 No. 02, Juni 2017, hlm. 168.

${ }^{3}$ Ibid.

${ }^{4}$ I. Tempat Kedudukan, BANI Rules \& Prosedur.
} 